\title{
Analisis Kemampuan Berpikir Kreatif Matematis Peserta Didik Ditinjau Dari Gender Dalam Pembelajaran Daring Pada Masa Covid-19 Di SMK
}

\author{
Devany Nur Masythoh ${ }^{1}$, Ishaq Nuriadin ${ }^{2}$ \\ 1,2 Pendidikan Matematika, Fakultas Keguruan dan Ilmu Pendidikan, Universitas Muhammadiyah Prof. Dr. Hamka \\ Jl. Tanah Merdeka No 20, Jakarta Timur, Indonesia \\ Devanynurm30@gmail.com
}

\begin{abstract}
Entering the 21st century, education in Indonesia is faced with a number of challenges and opportunities that are certainly different from the previous period. This study is a descriptive study with a qualitative approach that aims to analyze students' mathematical creative thinking skills in terms of gender in online learning during the covid-19 period in SMK. The subjects of this study were students of class X MM SMKN 1 Bekasi City, totaling 30 students consisting of 15 female students and 15 male students. The instrument in this study was a test of creative thinking skills. The test results of female students are found in indicators of flexibility, elaboration, and authenticity which are higher than the percentage of male students. Meanwhile, in the indicators of fluency, males are superior in percentage than female students. The conclusion of this study is that the mathematical creative thinking ability of female students is superior to the mathematical creative thinking ability of male students in solving problems on the material of sequences and series.
\end{abstract}

Keywords: Creative Thinking Skills, Online, Gender

\begin{abstract}
Abstrak
Memasuki abad ke 21, Pendidikan di Indonesia dihadapi dengan sejumlah tantangan dan peluang yang tentunya berbeda dengan pada masa sebelumnya. Penelitian ini merupakan penelitian deskriptif dengan pendekatan kualitatif yang bertujuan untuk menganalis kemampuan berpikir kreatif matematis peserta didik ditinjau dari gender dalam pembelajaran daring pada masa covid-19 di SMK. Subjek penelitian ini adalah peserta didik kelas X MM SMKN 1 Kota Bekasi yang berjumlah 30 peserta didik yang terdiri dari 15 peserta didik perempuan dan 15 peserta didik lakilaki. Instrumen pada penelitian ini adalah tes kemampuan berpikir kreatif. Hasil tes peserta didik perempuan terdapat di indikator keluwesan, elaborasi, dan keaslian yang lebih tinggi dibandingkan presemtase peserta dididk laki-laki. Sedangkan pada indikator kelancaran laki-laki lebih unggul dalam presentasenya dari peserta didik perempuan. kesimpulan dari penelitian ini adalah kemampuan berpikir kreatif matematis peserta didik perempuan lebih unggul dari pada kemampuan berpikir kreatif matematis peserta didik laki-laki dalam menyelesaian soal pada materi barisan dan deret.
\end{abstract}

Kata kunci: Kemampuan Berpikir Kreatif, Daring, Gender

Copyright (c) 2021 Devany Nur Masythoh, Ishaq Nuriadin

$\triangle$ Corresponding author: Devany Nur Masythoh

Email Address: Devanynurm30@gmail.com (Jl. Tanah Merdeka No 20, Jakarta Timur, Indonesia)

Received 21 June, Accepted 27 June 2021, Published 28 June 2021

\section{PENDAHULUAN}

Pandemik COVID-19 merupakan sebuah virus yang penularannya sangat cepat dan sulit untuk mengetahui ciri-ciri orang yang sudah terjangkit virus tersebut, karena masa inkubasinya kurang lebih dari 14 hari. Pandemik covid 19 telah membawa dampak keberbagai sektor, salah satunya ialah pada sektor pendidikan. Maka dalam kegiatan belajar mengajar terjadi perubahan yang tadinya dilakukan system luring (luar jaringan), saat ini dilakukan secarang daring atau PJJ (pembelajaran jarak jauh). Daring memberikan cara pembelajaran yang efektif, seperti berlatih dengan adanya feedback terkait, Adakalanya timbul berbagai masalah yang dihadapi oleh peserta didik dan guru, contohnya materi pembelajaran yang belum selesai disampaikan oleh guru kemudian guru mengganti dengan tugas lainnya (Rachmat \& Krisnadi, 2020). 
Memasuki abad ke 21, Pendidikan di Indonesia dihadapi dengan sejumlah tantangan dan peluang yang tentunya berbeda dengan pada masa sebelumnya. Pendidikan merupakan suatu hal yang penting dalam kehidupan manusia. Peran pendidikan sangatlah penting. Oleh karena itu pendidikan harus tetap dikembangkan dan dimaksimalkan. Mengingat pentingnya kreatif dalam pendidikan, pemerintah Indonesia mengintegrasikan kemampuan berpikir kreatif ke dalam kurikulum pendidikan hal ini telah dirumuskan dalam UU No. 20 tahun 2003 pasal 3 tentang Sistem Pendidikan Nasional yang bertujuan untuk mengembangkan potensi peserta didik agar menjadi manusia yang beriman dan bertakwa, berakhlak mulia, sehat, berilmu, cakap, kreatif, mandiri, dan menjadi warga Negara yang demokratis serta bertanggung jawab.

Kemampuan berpikir kreatif sangat penting dimiliki peserta didik dalam pembelajaran matematika. Berpikir kreatif merupakan suatu proses berpikir yang menghasilkan pandangan baru dari suatu permasalahan dan menghasilkan berbagai macam jawaban menurut (Widyastuti et al., 2018). (Meika \& Sujana, 2017) kemampuan berpikir kreatif merupakan kemampuan yang berkaitan dengan kreativitas yang dapat diartikan dengan mengembangkan suatu permasalahan, yang dilihat dari sisi berbeda permasalahan, dan memiliki ide terbuka dan pandangan yang luas. Adapun kemampuan berpikir kreatif menurut (Dilla et al., 2018) merupakan suatu kemampuan dalam matematika yang melingkup kelancaran, keluwesan, keaslian, dan elaborasi. (HAYLOCK, 1987) Mengatakan bahwa kemampuan berpikir kreatif matematis dapat menggunakan dua pendekatan, yang pertama dengan memperhatikan jawaban peserta didik dalam menyelesaikan masalah yang diproses kognitifnya dianggap sebagai proses berpikir kreatif, adapun yang kedua menentukan kriteria bagi sebuah produk yang diindikasikan sebagai hasil yang berpikir kreatif dinilai melalui gender.

Gender memiliki suatu peran kumpulan harapan yang menetapkan adanya perempuan atau laki-laki perlu berpikir, bertindak, dan berperasaan (Afandi, 2016), adapun menurut (Dilla et al., 2018) mengatakan bahwa beberapa peneliti percaya bahwa pengaruh faktor gender dalam matematika karena adanya perbedaan biologis dalam otak anak laki-laki dan perempuan yang diketahui melalui observasi, bahwa anak perempuan, secara umum, lebih unggul dalam bidang bahasa dan menulis, sedangkan anak laki-laki lebih unggul dalam bidang matematika karena kemampuan spasialnya yang lebih baik. Adapun menurut para ilmuan.

Banyak dari ilmuan melakukan penelitian tentang kemampuan berpikir kreatif matematis yang dilihat dari gender salah satunya (Simanjuntak et al., 2019) menunjukan bahwa siswa yang mempunyai tingkat kemampuan berpikir berbeda pula dengan tingkat kreatifnya. Adapun menurut (Widyastuti et al., 2018) bahwa kemampuan berpikir kreatif matematis siswa laki-laki lebih baik dari pada siswa perempuan dalam menyelesaikan masalah matematika. (Anwar et al., 2021) mengenai kemapuan berpikir kreatif matematis siswa dalam menyelasaikan masalah pada masa covid-19 dapat disimpulkan bahwa siswa memiliki tingkat 3 berpikir kreatifnya.

Berdasarkan uraian diatas tujuan penelitian ini adalah analisis kemapuan berpikir kreatif matematis peserta didik ditinjau dari gender dalam pembelajaran daring pada masa covid-19 di SMK. 


\section{METODE}

Jenis penelitian yang digunakan adalah penelitian deskriptif kualitatif. Penelitian deskriptif merupakan penelitian yang bertujuan untuk mengetahui keadaan dan kondisi yang mana hasilnya dijelaskan dalam bentuk laporan penelitian (Arikunto, 2010). Tujuan penelitian kualitatif merupakan memahami pandangan setiap individu, mengemukakan, dan menjelaskan proses, dan menggali informasi mendalam tentang subjek atau latar penelitian yang terbatas Putra, 2013:44 (dalam Putria et al., 2020). Teknik penggumpulan data dalam penelitian ini menggunakan tes kemampuan berpikir kreatif matematis. Subjek dalam penelitian ini adalah peserta didik kelas X MM SMKN 1 Kota Bekasi yang berjumlah 30 siswa yang terdiri dari 15 peserta didik perempuan dan 15 peserta didik laki-laki. Instrument pada penelitian ini berupa tes kemampuan berpikir kreatif matematis peserta didik dinilai dari gender.

\section{HASIL DAN DISKUSI}

\section{Hasil}

Penelitian ini dilaksanakan pada satu kelas X MM disalah satu SMKN 1 Kota Bekasi yyang berlokasi di Bintara, Bekasi Barat. Data hasil penelitian ini berupa belajar peserta didik yang pengumpulan datanya menggunakan instrument soal tes berupa uraian sebanyak 4 soal dengan setiap soal mengandung indikator kemampuan berpikir kreatif matematis pada materi barisan dan deret. Materi tersebut diperoleh peserta didik dengan pembelajaran daring (online). Data tes diperoleh dari analisis jawaban peserta didik berdasarkan acuan penskoran gender pada kemampuan berpikir kreatif matematis siswa dalam menyelesaikan soal.

Tabel 1. Deskripsi Indikator Kemampuan Berpikir Kreatif Peserta Didik Perempuan

\begin{tabular}{|c|c|c|c|c|c|}
\hline Jenis kelamin & Kelancaran & Keluwesan & Elaborasi & Keaslian & Jumlah \\
\hline $\mathbf{P}$ & 3 & 1 & 4 & 3 & 11 \\
\hline $\mathbf{P}$ & 4 & 1 & 1 & 4 & 10 \\
\hline $\mathbf{P}$ & 4 & 1 & 4 & 4 & 13 \\
\hline $\mathbf{P}$ & 1 & 1 & 1 & 4 & 7 \\
\hline $\mathbf{P}$ & 1 & 1 & 1 & 1 & 4 \\
\hline $\mathbf{P}$ & 4 & 1 & 3 & 4 & 12 \\
\hline $\mathbf{P}$ & 1 & 3 & 3 & 4 & 11 \\
\hline $\mathbf{P}$ & 4 & 4 & 4 & 4 & 16 \\
\hline $\mathbf{P}$ & 1 & 3 & 3 & 4 & 11 \\
\hline $\mathbf{P}$ & 4 & 1 & 3 & 4 & 12 \\
\hline $\mathbf{P}$ & 1 & 1 & 1 & 4 & 7 \\
\hline $\mathbf{P}$ & 4 & 2 & 4 & 4 & 14 \\
\hline $\mathbf{P}$ & 1 & 2 & 4 & 4 & 11 \\
\hline Jumlah keseluruhan & 1 & 2 & 4 & 4 & 11 \\
\hline
\end{tabular}


Tabel 2. Deskripsi Indikator Kemampuan Berpikir kreatif Perserta Didik Laki-laki

\begin{tabular}{|c|c|c|c|c|c|}
\hline Jenis Kelamin & Kelancaran & Keluwesan & Elaborasi & Keaslian & Jumlah \\
\hline L & 4 & 2 & 4 & 4 & 14 \\
\hline L & 2 & 1 & 3 & 4 & 10 \\
\hline L & 2 & 1 & 3 & 4 & 10 \\
\hline L & 4 & 1 & 3 & 4 & 12 \\
\hline L & 1 & 2 & 4 & 4 & 11 \\
\hline L & 1 & 1 & 1 & 1 & 4 \\
\hline L & 4 & 3 & 1 & 4 & 12 \\
\hline L & 4 & 2 & 1 & 4 & 11 \\
\hline L & 4 & 1 & 3 & 4 & 12 \\
\hline L & 1 & 1 & 3 & 1 & 6 \\
\hline L & 1 & 0 & 1 & 1 & 3 \\
\hline L & 4 & 1 & 1 & 4 & 10 \\
\hline L & 1 & 1 & 3 & 4 & 9 \\
\hline L & 4 & 1 & 4 & 4 & 13 \\
\hline Jumlah tiap indikator & 37 & 18 & 35 & 47 & 137 \\
\hline Jumlah keseluruhan & $61,67 \%$ & $30,00 \%$ & $58,33 \%$ & $78,33 \%$ & \\
\hline
\end{tabular}

Dibawah ini merupakan rekapulasi data statistik deskriptif kemampuan berpikir kreatif matematis.

Tabel 3. Persentase kemampuan berpikir kreatif matematis dalam gender

\begin{tabular}{|l|l|l|l|l|}
\hline Gender & Kelancaran & keluwesan & Elaborasi & Keaslian \\
\hline Perempuan & $56,67 \%$ & $40,00 \%$ & $66,67 \%$ & $86,67 \%$ \\
\hline Laki-laki & $61,67 \%$ & $30,00 \%$ & $58,33 \%$ & $78,33 \%$ \\
\hline
\end{tabular}

Hasil diperoleh dari:

$$
\text { persentase }=\frac{\text { jumlah tiap indikator }}{\text { jumlah keseluruhan }} \times 100 \%
$$

Berdasarkan data di atas hasil persentase kemampuan berpikir kreatif matematis dalam gender diperoleh bahwa peserta didik perempuan lebih unggul dalam indikator Keluwesan, Elaborasi, dan Keaslian dengan skor persentase masing- masing 40,00\%, 66,67\%, 86,67\%. Sedangkan pada peserta didik laki-laki hanya unggul di satu indikator yaitu indikator Kelancaran dengan skor presentase $61,67 \%$.

\section{Diskusi}

Pengambilan data di SMKN 1 Kota Bekasi, subjek penelitian terdiri dari 30 siswa kelas X Multimedia yang terdiri dari 15 siswa perempuan dan 15 siswa laki- laki. Peserta didik diberikan soal tes yang sudah disediakan dalam google form terdapat 4 soal dengan indikator kemampuan berpikir kreatif..Dilihat Dari hasil data yang diperoleh siswa perempuan lebih baik dari pada siswa laki-laki meskipun dari rubric penskoran hanya terdapat satu indikator yang maksimal.

Dapat dilihat dari indikator kelancaran penyelesaian peserta didik perempuan, terdapat enam peserta didik yang menjawab dengan memberikan lebih dari satu ide dengan penyelasaian yang lengkap dan jelas, selebihnya hanya memberikan ide tetapi penyelesaiannya kurang jelas. Adapun indikator keluwesan, 
sebagian besar peserta didik menjawab satu atau lebih cara tetapi terdapat kekeliruan dalam proses perhitungan. Selanjutnya indikator elaborasi, terdapat lima peserta didik yang memberikan jawaban lengkap dan tepat, sedangkan yang lainnya terdapat kesalahan dalam jawaban tetapi disertai langkah penyelesaian yang lengkap. Terakhir terdapat indikator keaslian dengan jumlah dua belas peserta didik yang memberikan jawaban dengan caranya sendiri dan hasilnya benar.

Adapun kemampuan berpikir kreatif matematis peserta didik laki-laki pada indikator kelancaran terdapat enam peserta didik yang memberikan lebih dari satu ide dengan penyelasaian yang lengkap dan jelas, sisanya hanya meberikan ide tetapi penyelesaiannya kurang jelas. Pada indikator keluwesan, sebagian besar peserta didik menjawab satu cara atau lebih tatapi jawaban salah. Selanjutnya indikator elaborasi, sebagian speserta didik terdapat kesalahan dalam jawaban tetapi disertai langkah yang legkap. Terakhir indikator keaslian terdapat peserta didik hampir keseluruhan memberikan jawaban dengan cara sendiri dan hasilnya benar. Secara keseluruhan peserta didik perempuan dapat memberikan jawaban dengan cara sendiri dengan perhitungan dan hasil yang benar, meskipun terdapat peserta didik perempuan yang belum memberikan jawaban lebih dari satu cara, dengan hasil perhitungan yang benar. Adapun peserta didik lakilaki yang cenderung hanya memberikan jawaban satu cara, tetapi jawabannya salah. Mereka hanya mengikuti proses pengerjaan yang diberikan oleh guru tanpa memahami bahwa proses tersebut. Hasil ratarata tes peserta didik perempuan dan peserta didik laki-laki dapat dilihat pada Gambar 1.

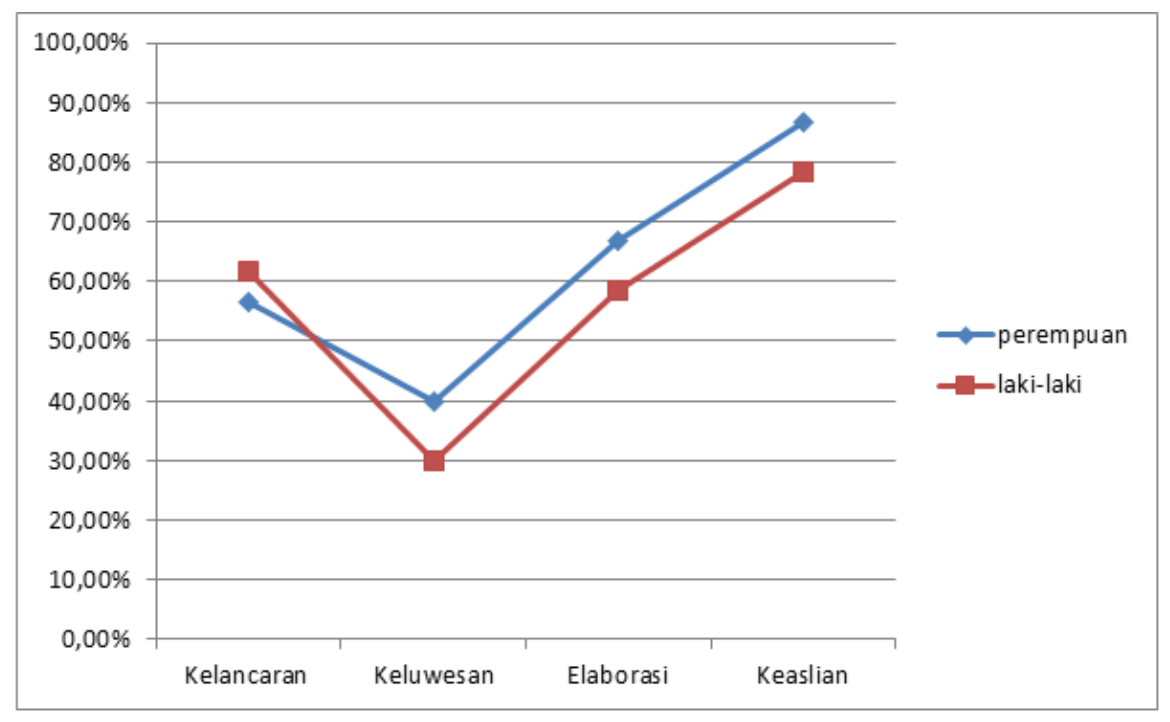

Gambar 1. Data Deskriptif kemampuan berpikir kreatif matematis

Hasil tes peserta didik perempuan terdapat diindikator keluwesan, elaborasi dan keaslian yang lebih tinggi presentasenya dari pada presetase peserta didik laki-laki. Sedangkan pada indikator kelancaran peserta didik laki-laki lebih unggul dalam presentasenya dari pada peserta didik perempuan dan dapat dilihat pada gambar 1diatas. Berdasarkan penjelasan di atas bahwa peserta didik perempuan memiliki kemampuan berpikir kreatif matematis yang lebih unggul dari peserta didik laki-laki. Hal ini diperkuat oleh penelitian (Dilla et al., 2018) yang menyatakan bahwa kemampuan berpikir kreatif di ungguli oleh siswa perempuan 
karena siswa laki-laki cenderung memiliki rasa kurang percaya diri.

\section{KESIMPULAN}

Dari hasil dan Diskusi, dapat disimpulkan dari penelitian ini adalah kemampuan berpikir kreatif matematis peserta didik perempuan lebih unggul dari pada kemampuan berpikir kreatif matematis peserta didik laki-laki dalam menyelesaikan soal pada materi barisan dan deret. Maka dari itu factor gender mempengaruhi kemampuan berpikir kreatif matematis peserta didik.

\section{UCAPAN TERIMA KASIH}

Ucapan terima kasih saya berikan kepada kedua orang tua yang telah mensupport saya. Kemudian kepada Dosen Pembimbing saya yaitu Bapak Dr. Ishaq Nuriadin,M.Pd, serta teman-teman saya yang telah memberi dukungan dalam menyelesaikan penelitian ini.

\section{REFERENSI}

Afandi, A. (2016). Profil Penalaran Deduktif Siswa Smp Dalam Menyelesaikan Masalah Geometri Berdasarkan Perbedaan Gender. APOTEMA : Jurnal Program Studi Pendidikan Matematika, 2(1), 8 21. https://doi.org/10.31597/ja.v2i1.123

Anwar, E. S., Wibowo, T., \& Maryam, I. (2021). BERPIKIR KREATIF SISWA DALAM MENYELESAIKAN MASALAH MATEMATIKA DI MASA PANDEMI COVID-19. EKSAKTA : Jurnal Penelitian Dan Pembelajaran MIPA, 6(22), 29-36.

Arikunto, S. (2010). Prosedur Penelitian Suatu Pendekatan Praktik. 2010. Jakarta: Rineka Cipta.

Dilla, S. C., Hidayat, W., \& Rohaeti, E. E. (2018). Faktor Gender dan Resiliensi dalam Pencapaian Kemampuan Berpikir Kreatif Matematis Siswa SMA. Journal of Medives : Journal of Mathematics Education IKIP Veteran Semarang, 2(1), 129. https://doi.org/10.31331/medives.v2i1.553

HAYLOCK, D. W. (1987). Mathematical Creativity in Schoolchildren. The Journal of Creative Behavior, 21(1), 48-59. https://doi.org/10.1002/j.2162-6057.1987.tb00452.x

Meika, I., \& Sujana, A. (2017). Kemampuan Berpikir Kreatif Dan Pemecahan Masalah Matematis Siswa SMA. Jurnal Penelitian Dan Pembelajaran Matematika. https://doi.org/10.30870/jppm.v10i2.2025

Putria, H., Maula, L. H., \& Uswatun, D. A. (2020). Analisis Proses Pembelajaran dalam Jaringan (DARING) Masa Pandemi Covid- 19 Pada Guru Sekolah Dasar. Jurnal Basicedu, 4(4), 861-870. https://doi.org/10.31004/basicedu.v4i4.460

Rachmat, A., \& Krisnadi, I. (2020). Analisis Efektifitas Pembelajaran Daring ( Online ) Untuk Siswa Smk Negeri 8 Kota Tangerang Pada Saat Pandemi Covid 19.

Simanjuntak, E., Hia, Y., \& Manurung, N. (2019). Analisis Kemampuan Berpikir Kreatif dalam Pemecahan Masalah Ditinjau Dari Perbedaan Gender. School Education Journal, 9(3), 213-220.

Widyastuti, A. C., Permana, D., \& Sari, I. P. (2018). Analisis Kemampuan Berpikir Kreatif Matematis Siswa Dalam Menyelesaikan Masalah Matematika Pada Materi Bangun Ruang Sisi Datar Dilihat Dari 
$\begin{array}{llllll}\text { Gender. JPMI (Jurnal Pembelajaran } & \text { Matematika Inovatif), } & \text { l(2), } & 145 .\end{array}$ https://doi.org/10.22460/jpmi.v1i2.p145-148 